\title{
Do Institutional Transplants Succeed? Regulating Raiffeisen Cooperatives in South India, 1930-1960
}

The government in British-ruled India established cooperative banks to compete with private moneylenders in the rural credit market. State officials expected greater competition to increase the supply of low-cost credit, thereby expanding investment potential for the rural poor. Cooperatives did increase credit supply but captured a small share of the credit market and reported net losses throughout the late colonial and early postcolonial period. The article asks why this experiment did not succeed and offers two explanations. First, low savings restricted the role of social capital and mutual supervision as methods of financial regulation in the cooperative sector. Second, a political-economic ideology that privileged equity over efficiency made for weak administrative regulation.

Keywords: rural banking, agriculture, India, colonialism, institutional change

\footnotetext{
A griculture was the largest yet least productive sector of the Indian economy during the colonial period. ${ }^{1}$ Underdeveloped financial
}

I am especially grateful to Tirthankar Roy and Gerben Bakker for their feedback and support. I thank Chris Colvin, Karolina Hutkova, and two anonymous referees for their invaluable comments. Early versions of the paper benefited from discussions at the Economic and Social History graduate seminar at the University of Oxford and the graduate seminar in Economic History at the London School of Economics. I also thank the Economic History Society for financial support. Any errors are my own.

${ }^{1}$ B. R. Tomlinson, The Economy of Modern India, 1860-1970 (Cambridge, U.K., 1993); Latika Chaudhary, Bishnupriya Gupta, Tirthankar Roy, and Anand V. Swamy, A New Economic History of Colonial India (New York, 2015).

Business History Review 95 (Spring 2021): 59-85. doi:10.1017/Sooo7680520000884 (C) 2021 The President and Fellows of Harvard College. ISSN 0007-6805; 2044-768X (Web). This is an Open Access article, distributed under the terms of the Creative Commons Attribution licence (http://creativecommons.org/licenses/by/4.o/), which permits unrestricted re-use, distribution, and reproduction in any medium, provided the original work is properly cited. 


\section{Maanik Nath / 60}

markets, it is widely believed, are one root of the problem. ${ }^{2}$ Private moneylenders controlled the supply of credit to rich and poor peasants in rural India. The colonial government believed that investment rates were low and the price of credit was high because markets were supply-constrained and noncompetitive. Policy initiatives in the early twentieth century established competing sources of credit to rival private creditors. Officials in the colonial government expected greater market competition to increase the supply of low-cost rural credit. However, the high risk of lending in the Indian countryside was a barrier to entry for commercial banks. Cultivation was seasonal and dependent on unpredictable rainfall patterns. Crop failure was common, leading to high default rates. ${ }^{3}$ Inefficient courts as well as limited use of bills and negotiated instruments restrained institutional development in the market for agricultural credit. ${ }^{4}$

Cooperative banking offered a potential solution to the problem. 5 Contemporary studies on Raiffeisen cooperatives in Western Europe referred to these as models to follow. ${ }^{6}$ Present-day scholarship endorses that view. Cooperatives in Germany and the Netherlands provided credit to the poor and reported profits in the nineteenth and early twentieth centuries. ${ }^{7}$ Scholars explain their success by highlighting two key preconditions for successful cooperative banking. ${ }^{8}$ First, cooperatives

\footnotetext{
${ }^{2}$ Amiya K. Bagchi, "Land Tax, Property Rights and Peasant Insecurity in Colonial India," Journal of Peasant Studies 20, no. 1 (1992): 1-49; Sugata Bose, Credit, Markets, and the Agrarian Economy of Colonial India (New York, 1994); David Hardiman, Feeding the Baniya: Peasants and Usurers in Western India (New Delhi, 1996).

${ }^{3}$ Tirthankar Roy, "The Monsoon and the Market for Money in Late-Colonial India," Enterprise \& Society 17, no. 2 (2016): 324-57.

${ }^{4}$ Tirthankar Roy and Anand V. Swamy, Law and the Economy in Colonial India (Chicago, 2016).

${ }^{5}$ Joseph E. Stiglitz, "Peer Monitoring and Credit Markets," World Bank Economic Review 4, no. 3 (1990): 351-66; Timothy Besley and Stephen Coate, "Group Lending, Repayment Incentives and Social Collateral," Journal of Development Economics 46, no. 1 (1995): 1-18; Maitreesh Ghatak, "Screening by the Company You Keep: Joint Liability Lending and the Peer Selection Effect," Economic Journal 110, no. 465 (2000): 601-31. Each broadly agrees that group lending arrangements can, under certain conditions, deliver a structure of risk sharing that reduces information and enforcement costs.

${ }^{6}$ Malcolm Darling, Some Aspects of Co-operation in Germany, Italy and Ireland (Lahore, 1922).

${ }^{7}$ Abhijit V. Banerjee, Timothy Besley, and Timothy W. Guinnane, “Thy Neighbor's Keeper: The Design of a Credit Cooperative with Theory and a Test," Quarterly Journal of Economics 109, no. 2 (1994): 491-515; Maitreesh Ghatak and Timothy W. Guinnane, "The Economics of Lending with Joint Liability: Theory and Practice," Journal of Development Economics 60, no. 1 (1999): 195-228.

${ }^{8}$ Timothy W. Guinnane, “A Failed Institutional Transplant: Raiffeisen's Credit Cooperatives in Ireland, 1894-1914," Explorations in Economic History 31, no. 1 (1994): 38-61; Guinnane, "Cooperatives as Information Machines: German Rural Credit Cooperatives, 18831914," Journal of Economic History 61, no. 2 (2001): 366-89; Guinnane, "A 'Friend and Advisor': External Auditing and Confidence in Germany's Credit Cooperatives, 1889-1914," Business History Review 77, no. 2 (2003): 235-64; Christopher L. Colvin and Eoin McLaughlin, "Raiffeisenism Abroad: Why Did German Cooperative Banking Fail in Ireland but Prosper
} 
were self-funded within small membership groups. Rich and poor peasants saved in local cooperatives, while a high ratio of savings to external borrowing ensured banks were not overleveraged. Second, governments in Western Europe implemented regulatory and supervision structures that ensured cooperatives were well managed. In the context of high savings and strong regulation, members absorbed the risk of lending, which not only allowed German and Dutch cooperatives to form a source of low-cost credit for peasants but also guaranteed their profitability and resilience to crisis. ${ }^{9}$

Early to mid-twentieth-century India presents a useful case study of cooperatives. Cooperatives were a state-driven initiative in India and the colonial government set up the first Indian cooperative in the Madras province in 1904. ${ }^{10}$ The success of rural cooperatives in Europe had inspired this initiative. According to an Indian economist in the 1930s, "the study of the small village banks in Germany toward the close of the last century attracted the attention of those who were eager to solve the problem of rural poverty." ${ }^{11}$ Policymakers in colonial and postcolonial India continued to invest their confidence in the cooperative movement as a solution to the credit problem. They believed that "great things were expected of the cooperative movement in India, on the analogy of its phenomenal success in Europe."12

This article shows that the transplanted cooperative banking model did not perform well in India. The cooperative sector grew exponentially in the early to mid-twentieth century. The size of the cooperative sector in 1950 Madras mirrored that of Germany at the turn of the century. ${ }^{13}$ However, cooperatives failed to displace the village moneylender. Managers of cooperatives selectively allocated loans and, despite this selective allocation, the cooperative sector was unprofitable.

in the Netherlands?," Economic History Review 67, no. 2 (2014): 492-516; Colvin, "Banking on a Religious Divide: Accounting for the Success of the Netherlands' Raiffeisen Cooperatives in the Crisis of the 1920s," Journal of Economic History 77, no. 3 (2017): 866-919.

${ }^{9}$ Colvin emphasizes the importance of religious institutions in supervising the allocation of loans. Colvin, "Banking on a Religious Divide."

${ }^{10}$ In India, cooperatives could not be formed without legal authorization. This authorization did not come from banking or company law. Laws executed by the Cooperative Societies Department determined the guidelines for credit cooperatives to operate. Credit outfits operating within these guidelines could register as cooperatives. Laws referred to cooperatives as "banks" and "societies." This article follows this terminology and uses the terms interchangeably. Commercial banks did not lend in rural Madras before 1960.

${ }^{11}$ Krishna K. Sharma, The Indian Money Market (Bangalore, 1934), 63.

${ }^{12}$ Report on Agricultural Indebtedness (Madras, 1935), 58.

${ }^{13}$ Guinnane estimates that nineteen thousand cooperative banks operated in Germany in 1914. Over seventeen thousand banks operated in Madras in 1952. Guinnane, "Friend and Advisor," 237. 
Table 1

Principles of a Raiffeisen Cooperative

Feature

Self-funded

Self-supervised

Externally Regulated
Outcome

Rich and poor save in banks. Defaults diminish savings.

In fear of losing savings to bad loans, members identify

creditworthy borrowers and enforce the repayment of loans through social sanctions.

Regulators hold managers accountable.

Sources: Abhijit V. Banerjee, Timothy Besley, and Timothy W. Guinnane, "Thy Neighbor's Keeper: The Design of a Credit Cooperative with Theory and a Test," Quarterly Journal of Economics 109, no. 2 (1994): 491-515; Maitreesh Ghatak and Timothy W. Guinnane, "The Economics of Lending with Joint Liability: Theory and Practice," Journal of Development Economics 60, no. 1 (1999): 195-228.

Why did the experiment fail to achieve its main aims? The article argues that administrators in late colonial and early postcolonial India designed a cooperative model that differed from the European model in important ways. Prevailing political objectives prioritizing equity over efficiency led to a cooperative structure operating with low savings and weak regulation. The regulatory problem ultimately led to the exclusion of poorer peasants from accessing credit and overleveraged cooperative banks.

What was the problem with regulation? The stylized model of Raiffeisen banking in Europe suggests that cooperatives could succeed because savings rates were high. In Madras, however, poor peasants did not raise enough capital and rich peasants refused to save in village cooperatives. Depositors were few and members-cum-borrowers were plenty, restricting the role of social capital and self-supervision as regulatory mechanisms. Contrary to the European model where poorly resourced banks could succeed if they were well regulated, cooperatives in rural Madras were regulated by administrative bodies that did not enforce competent banking regulation. The Indian government created the first Banking Regulation Act in 1949 and it did not cover cooperatives. Specific laws passed by the governments in the provinces regulated cooperatives in the colonial and early postcolonial period. Political and organizational interests overlapped, leading to the mismanagement of cooperative banks. Postcolonial Indian governments injected public money into the cooperative sector in the belief that this would increase credit access for poor borrowers. However, flaws in regulatory design persisted, allowing managers to falsify accounts, embezzle, and insider-lend.

The article's contribution is threefold. First, it contributes to a regionally underresearched topic. Nikolay Kamenov, in a recent article 
on cooperatives in India, observed that "what seems prima facie striking for a historical issue of such significance is the sparse attention the theme has generated over the last couple of decades."14 The existing literature provides a discussion on sociopolitical barriers to cooperation. ${ }^{15}$ Instead, this article considers the design of the transplanted cooperative banking model as an explanation for its nonperformance. Second, it adds a region of comparison to the global business and economic history of credit cooperatives. The existing scholarship is largely Eurocentric, despite the emergence, and rapid rise in the number, of cooperative banks in British colonies in the early twentieth century. ${ }^{16}$ Analyzing the performance of cooperatives in India offers a benchmark for further contributions on similar transplants in other colonial contexts. Third, the article uses a previously unexplored group of primary sources that report on the cooperative sector in rural Madras from 1930 to 1960 . As cooperatives were a state-driven initiative, officials in the Indian provinces regularly recorded key performance measures of the cooperative sector. The article combines data from these government reports with new case judgments from provincial courts.

The article is divided into four sections. The first provides background on agriculture in Madras, the political motivations for introducing cooperatives, and a summary of key features of the cooperative model in the province. The second traces the expansion of the cooperative sector and its lack of profitability in the early to mid-twentieth century. The third demonstrates that cooperatives were mismanaged because of low savings and weak regulation. The fourth shows that state financing in the 1940 s sustained failing cooperatives but prolonged flaws in the sector's regulatory structure.

\footnotetext{
${ }^{14}$ Nikolay Kamenov, "The Place of the 'Cooperative' in the Agrarian History of India, c. 1900-1970," Journal of Asian Studies 79, no 1 (2020): 103-28.

${ }^{15}$ This literature suggests that political elites captured rents form cooperatives but does not fully explain why this was the case. Ian J. Catanach, Rural Credit in Western India, 18751930: Rural Credit and the Co-operative Movement in the Bombay Presidency (Berkeley, 1970); Bruce Robert, "Agricultural Credit Cooperatives in Madras, 1893-1937: Rural Development and Agrarian Politics in Pre-independence India," Indian Economic and Social History Review 16, no. 2 (1979): 163-84; Iftekhar Iqbal, "Cooperative Credit in Colonial Bengal: An Exploration in Development and Decline, 1905-1947," Indian Economic and Social History Review 54, no. 2 (2017): 221-37.

${ }^{16}$ For example, there is little research on the history of cooperatives in British-ruled African colonies. On the politics of cooperatives in mid-twentieth-century South Africa and Zambia, see Paul B. Rich, "Bernard Huss and the Experiment in African Cooperatives in South Africa, 1926-1948," International Journal of African Historical Studies 26, no. 2 (1993): 297-317; and Andrew Bowman, "Mass Production or Production by the Masses? Tractors, Cooperatives, and the Politics of Rural Development in Post-independence Zambia," Journal of African History 52, no. 2 (2011): 201-21. On the cooperative movement in Nigeria, see Samuel Oladele Adeyeye, The Co-operative Movement in Nigeria Yesterday, Today and Tomorrow (Gottingen, 1978).
} 


\section{Maanik Nath / 64}

\section{Agriculture, Credit, and the Cooperative Model}

The majority of India's population lived in rural areas and were employed in agriculture during the colonial and early postcolonial period. Markets developed and expanded in the nineteenth century, aided by a growth in road and railway construction. ${ }^{17}$ However, by all measures, agriculture performed poorly in Madras and across most of India until roughly 1960 . GDP and productivity in agriculture grew modestly throughout colonial rule. ${ }^{18}$ In the same period, population grew rapidly and the share of the labor force in agriculture remained stagnant. ${ }^{19}$ Low investment constrained innovation as production processes remained trapped in a low-yielding regime. ${ }^{20}$ Rural Madras, as with the rest of colonial India, contended with poor-quality soil, limited irrigation, and unpredictable rainfall patterns. High demand and volatile supply led to frequent food shortages, with some years of mass famine. Cheaper credit, for consumption and production, could potentially redress subsistence crises and improve investment rates. But credit was expensive in rural India.

Private, informal credit was an important input in rural India during the colonial period. Rich and poor peasants had little access to formal banking in the countryside and relied on moneylenders for credit. The credit market in Madras presented distinct features, relative to markets in other provinces. Whereas traders and financiers from the cities extended credit in the agricultural sector in Bombay and Punjab, cultivators were the sole suppliers of credit in rural Madras. ${ }^{21}$ A government report in 1930 noted that moneylending in villages was "from one ryot (cultivator) to another while the rural moneylender who does nothing but lend is rare." ${ }^{22}$ Several moneylenders operated within

\footnotetext{
${ }^{17}$ John Hurd, "Railways and the Expansion of Markets in India, 1861-1921," Explorations in Economic History 12, no. 3 (1975): 263-68.

${ }^{18}$ Alan Heston, "National Income," in The Cambridge Economic History of India, vol. 2, c.1757-c.1970, ed. Dharma Kumar and Meghnad Desai (Cambridge, U.K., 1983), 376-462; S. Sivasubramoniam, National Income of India in the Twentieth Century (Oxford, 2000).

${ }^{19}$ Christopher Baker, "Colonial Rule and the Internal Economy in Twentieth-Century Madras," Modern Asian Studies 15, no. 3 (1981): 575-602; David A. Washbrook, "Colonialism, Globalization and the Economy of South-East India, C.1700-1900" (Working Papers of the Global Economic History Network [GEHN], No. 24/06, 2005).

${ }^{20}$ Christopher Baker approaches rural development in Madras as a conflict between rising demand and the scarcity of "productive resources." Baker, An Indian Rural Economy, 188o1955: The Tamilnad Countryside (Oxford, 1984), 136.

${ }^{21}$ Official reports in colonial India distinguish the moneylenders as "professional" or "agriculturist." The reports suggest that financiers from the Gujarati and Marwari communities were professional moneylenders and supplied credit in rural Bombay and Punjab. In contrast, cultivators with disposable income were agriculturist moneylenders and supplied credit to other cultivators in Madras. See Report on Agricultural Indebtedness, 43.

${ }^{22}$ Madras Provincial Banking Enquiry Report, vol. 1 (Madras, 1930), 220.
} 


\section{Do Institutional Transplants Succeed? / 65}

villages. Large landowners did lend money, as did smaller landowners and tenant cultivators with disposable income. ${ }^{23}$ Moneylenders were numerous but the cost of credit was high in Madras. Moneylenders charged monthly rather than annual interest rates. A survey of the Bellary district in colonial Madras noted that rates varied "from 1 to 2.5 per cent per mensem." ${ }^{24}$ Compounded annually, moneylenders commonly charged an interest rate of between 12 and 24 percent per annum in the early to mid-twentieth century. ${ }^{25}$

Officers in the colonial government claimed that exploitation in rural credit markets depressed growth and widened inequality in rural India. Average landholdings were small. The average landholding in late-1920s India was approximately six acres-one-tenth the size of the average holding in Britain and just over one-fifth the size of the average holding in the Netherlands. ${ }^{26}$ Government surveyors typically classified small landholders as those owning less than five acres of land and large landholders as those owning above twenty-five acres. Historians show that land ownership was either fragmented into multiple smallholdings or concentrated at the top end of the ownership structure, leaving a fractional subsection in the middle. ${ }^{27}$ The colonial government acknowledged this but believed that the problem persisted through elite capture in rural credit markets. In the government's interpretation, poor borrowers defaulted on expensive loans to wealthy landowners, leading to transfers of land from peasants to richer cultivators. ${ }^{28}$ Accordingly, officials targeted diminishing exploitation in rural credit as a broader strategy to address rising inequality. ${ }^{29}$

Government intervention took two forms. First, provincial legislators regulated moneylenders through usury laws. ${ }^{30}$ Second, colonial

${ }^{23}$ District surveyors in the 1930 documented the number of moneylenders in select villages. The Provincial Banking Enquiry Report commented that "there are moneylenders everywhere" (220). The Report on Agricultural Indebtedness found that twenty-four moneylenders operated in one village in the East Godavari district.

${ }^{24}$ Madras District Gazetteers: Bellary, vol. 1 (Madras, 1915), 101.

${ }^{25}$ Provincial Banking Enquiry Report, 221.

${ }^{26}$ Claude F. Strickland, "Coöperation and the Rural Problem of India," Quarterly Journal of Economics 43, no. 3 (1929): 504.

${ }^{27}$ David Washbrook, "Country Politics: Madras 1880 to 1930," Modern Asian Studies 7, no. 3 (1973): 476-80; Dharma Kumar, "Landownership and Inequality in Madras Presidency: 1853-54 to 1946-47," Indian Economic and Social History Review 12, no. 3 (1975): 229-61.

${ }^{28}$ S. S. Thorburn, a civil servant in the Punjab province, believed that rich landowners held poor peasants in persistent debt bondage during the late nineteenth century. See Septimus Smet Thorburn, Musalmans and Money-Lenders in the Punjab (London, 1886).

${ }^{29}$ The colonial government believed that inequality motivated conflict in the countryside. Officials in the Bombay Presidency saw the 1870 os Deccan Riots as a conflict between poor peasants and rich moneylenders. See Catanach, Rural Credit.

${ }^{30}$ The government in Madras enforced an interest rate ceiling on loans from moneylenders in the mid-1930s. 


\section{Maanik Nath / 66}

officials acted on a belief that competition from regulated cooperatives in villages would disrupt the market power of private lenders. Indeed, cooperatives became the focal point of the government's rural development strategy in the early twentieth century.

The colonial government conducted research on successful cooperative banking experiments in Europe prior to transplanting the model in India. In an 1895 government report on "the possibility of introducing land and agricultural banks into the Madras Presidency," Frederick Nicholson surveyed credit cooperatives in Europe and suggested the conditions required for the transplant of a similar banking experiment in India. ${ }^{31}$ Nicholson asserted support for rural cooperatives and concluded the report with the phrase "Find Raiffeisen." 32 Nicholson identified three essential principles of Raiffeisen cooperation in Europe: first, the membership of each cooperative bank remained small and localized; second, cooperative banks were self-funded through members' savings; and third, cooperative banks determined the creditworthiness of borrowers by "personal character" rather than by land or physical collateral.33 Nicholson's report convinced the government of the benefits of cooperative banking. The provincial government in Madras established rural cooperatives in 1904, the same year that Nicholson retired from government service. As such, Nicholson did not participate in the implementation of the cooperative transplant. The government, with limited input from Nicholson, enforced laws in the early twentieth century that determined the capital and regulatory structure of the cooperative movement. ${ }^{34}$ Did the implemented model facilitate rural cooperation?

If the aim was to expand the supply of credit in villages, that aim was initially met to a small extent. Cooperatives accepted deposits from members and nonmembers, hoping these deposits would finance the expansion in credit supply. 35 By 1905 , it became clear to policymakers that cooperatives struggled to raise savings from villages alone. ${ }^{36}$ The government, still focused on expanding credit supply, created a threetier banking structure to compensate for the low level of savings in villages. The provincial government established the Madras Central

${ }^{31}$ Frederick Augustus Nicholson joined the Indian Civil Service in 1869. Nicholson was stationed in the Madras Presidency and was promoted from the lower ranks of district administrator to member of the Legislative Council in 1897. Colonial and postcolonial administrators credited Nicholson for his detailed reports on famine and rural banking.

${ }^{32}$ Report regarding the Possibility of Introducing Land and Agricultural Banks into the Madras Presidency (Madras, 1897), 185.

${ }^{33}$ Report regarding the Possibility.

${ }^{34}$ The 1904 and 1912 Cooperative Societies Acts provided guidelines within which cooperative banks operated.

${ }^{35}$ The law stipulated that cooperatives could only lend to members.

${ }^{36}$ The Madras Co-operative Manual (Madras, 1921), 7. 
Urban Bank (MCUB), which accepted deposits from members and nonmembers in metropolitan Madras. The MCUB provided credit to primary banks. ${ }^{37}$ The number of primary banks increased in the early twentieth century, exceeding the financial scope of the MCUB. The government created district banks to provide loans to primary banks in 1909. District banks were funded by three groups: first, members and nonmembers saved and owned shares in district banks; second, primary banks deposited reserves into district banks; and third, municipal- and district-level government departments saved public money in district banks. District banks would lend not to individual borrowers but exclusively to primary banks. By 1930, the cooperative three-tier structure included primary banks as creditors to cultivators in villages, apex district banks, and an apex provincial bank as feeders to primary banks. In developing this cooperative model, the government succeeded in expanding the supply of credit but made internal supervision challenging, as a later section will show.

The government supplemented the expansion in credit supply with rules that stipulated the participation of poor peasants in the management of primary banks. The government needed rich peasants to participate in order to keep savings high and cooperatives self-funded. Yet it also needed to ensure that banks were not hijacked by richer cultivators that wielded greater social and political power in the countryside. As prescribed by the provincial government in Madras, a panchayat, or governing board of five managers, including one president and one secretary, managed each primary bank. ${ }^{38}$ Members of each primary bank elected its panchayat. 39 Once elected, managers were either honorary or professionally employed and paid an annual remuneration by the bank. $4^{\circ}$ The colonial government established supervising unions in 1910 to ensure transparency in the management of primary banks. ${ }^{41}$ Supervising

\footnotetext{
${ }^{37}$ The MCUB later changed its name to the Madras Provincial Cooperative Bank.

${ }^{38}$ The Cooperatives Societies Acts in 1904 and 1912 did not specify management structure. In 1914, a federal committee under the leadership of Edward Douglas MacLagan, a provincial legislator in Punjab, reported on the ideal management structure of primary banks. Five years later, the federal government delegated the power to legislate in the cooperative sector to governments in the individual provinces. Following guidance in the MacLagan Committee's report, the provincial government in early 1920 s Madras formally established election rules as well as the roles and responsibilities of the elected managers.

${ }^{39}$ In the late colonial period, primary banks held annual general meetings where members elected managers. Laws in the postcolonial period stipulated elections every three years.

${ }^{40}$ Rural Credit Follow-Up Survey (Bombay, 1960), 441.

${ }^{41}$ The provincial government grouped primary banks that were in close proximity to each other into unions. The aim was for managers from one primary bank to supervise and advise managers from another. The government implemented this policy to avoid the additional expenses of appointing external supervisors (Co-operative Manual, 36). Unions did not audit primary banks. The government undertook this responsibility in the 1920s, as discussed in a later section.
} 


\section{Table 2}

Structure of Cooperative Banking in Madras

\begin{tabular}{ll}
\hline Organization c. 1930 & \multicolumn{1}{c}{ Role } \\
Government & $\begin{array}{l}\text { Enforced laws and regulated cooperative banks. } \\
\text { Savings bank in the city. Provided a small amount of credit to } \\
\text { district and primary banks. }\end{array}$ \\
District bank & $\begin{array}{c}\text { A savings bank for members, nonmembers, primary banks and } \\
\text { local government. Provided credit to primary banks. } \\
\text { Primary bank }\end{array}$ \\
& $\begin{array}{c}\text { A savings bank for members and nonmembers. Lending bank } \\
\text { for members in rural villages. }\end{array}$ \\
\hline
\end{tabular}

Source: The Madras Co-operative Manual (Madras, 1921).

unions performed two tasks: they reviewed the lending operations of primary banks and reported on the profile of borrowers, and they judged applications made by primary banks for loans from district banks. ${ }^{42}$ Unions submitted annual reports of primary banks to their district bank creditors. In theory, reports from supervising unions identified management problems, including banks where rich managers discriminated against poor peasants.

The caste system was one potential barrier to cooperation in the Indian countryside. The government considered the diversity of membership a vital determinant of the success of the cooperative movement. Official reports classified members of primary banks by religion and caste. Surveyors recorded six categories, including "Non-Brahmans, Brahmans, Adi-Dravidas, Christians, Muhammadans and other classes." Reports that classified members by groups of "Brahman" and "Non-Brahman" attempted to create a clear distinction between socioeconomic classes. Government officials considered Brahmans as richer landowners and lower castes as smallholders and tenants. According to one provincial report in 1929, 12 percent of members were Brahmans, 63 percent were "Non-Brahman," and 25 percent were from other religions and castes. 43 The provincial government celebrated this outcome. From these numbers, there was diversity in the voting membership group of each primary bank. However, contrary to the government's view, the presence of diversity alone was not enough to suggest cooperation. External supervision was needed to ensure one group did not discriminate against another. As subsequent sections will show, the supervising unions did not perform this role successfully.

\footnotetext{
${ }^{42}$ Annual Report on the Working of the Co-operative Credit Societies Act 1929 (Madras, 1928-1939), 25-26.

${ }^{43}$ Annual Report 1929, 10.
} 


\section{Performance Puzzle: Expansion but Unprofitable}

By all measures, the size of the cooperative banking sector in rural Madras increased by a significant margin during the first half of the twentieth century. Between 1907 and 1929, the number of cooperative banks increased from 63 to $15,238 .{ }^{4}$ By 1952, there were 17,201 primary banks, of which 16,616 banks operated with unlimited liability and 88 banks operated with limited liability. 45 Membership, total working capital and the value of loans provided by primary banks more than doubled between 1928 and 1953. Total membership in primary banks increased from 652,285 in 1929 to $1,537,000$ in $1953 .{ }^{46}$ The number of district banks remained stagnant, at between 14 and 16 throughout the period, whereas the number of primary banks linked to each apex bank doubled between 1940 and $1955 .{ }^{47}$ There was also a rise in the average number of members per primary bank between 1928 and $1955.4^{4}$ The Rural Credit Survey estimated that primary banks had an average membership of eighty-eight in the 1950s.49 This was lower than similar estimations in nineteenth-century Germany. ${ }^{\circ}$ The rise in the number of village banks was supplemented by a rise in membership, implying an increase in the number of cultivators with access to cooperatives.

The price of credit from cooperatives was an added success. Cooperatives charged lower interest rates than moneylenders. The government enforced a ceiling on the interest rates charged by primary banks. Rates fluctuated between 7.5 percent and 9.5 percent per annum in the early 1930s. As discussed, moneylenders in the same period charged rates of 2 percent per month. Under these conditions, the data suggests an expansion in the supply of low-cost credit during the early to mid-twentieth century.

It is surprising, then, that cooperatives failed to capture a sizable share of the credit market. A survey in 1935 estimated that credit from cooperatives accounted for just 6 percent of all loans to cultivators. ${ }^{11}$ A similar report in 1956 provides a figure of just 3 percent across

\footnotetext{
${ }^{44}$ B. V. Narayanaswami Naidu, "The Co-operative Movement in the Madras Presidency," Indian Journal of Economics 14 (1934): 426.

${ }^{45}$ Rural Credit Survey, 220; Report of the Committee on Co-operation in Madras (Madras, 1956), 425.

${ }^{46}$ Annual Reports 1928-1939; Report of the Committee 1956.

${ }^{47}$ Report of the Committee 1956, 425.

${ }^{48}$ Annual Reports 1928-39; Report of the Committee 1956.

${ }^{49}$ Rural Credit Survey, vol. 2 (Bombay, 1954), 216.

${ }^{50}$ Guinnane, in "Failed Institutional Transplant," shows that the average membership size of Raiffeissen cooperatives in Germany fluctuated between seventy-five and two hundred.

${ }^{51}$ Report on Agricultural Indebtedness, 40.
} 
India while confirming similar results for the market in Madras. ${ }^{2}$ B. V. Narayanaswamy Naidu, a provincial legislator in the Madras government, suggested that 7.9 percent of rural households were members of credit cooperatives in the mid-1930s. ${ }^{53}$ Similarly, 23.5 percent of the provincial rural population were "within the fold of rural credit cooperatives," with a small share of this group actually borrowing from cooperative banks in 1956, demonstrating that the lack of market penetration persisted throughout the period. 54

Cultivators did not benefit equally from the expansion of cooperative credit. Borrowers were concentrated in a small subsection of the rural population. Primary banks selectively allocated loans to richer peasants. Government reports in the 1950 os recognized this problem. According to the Rural Credit Survey, "small owners, tenants-at-will and labourers, the cultivators of areas with poor rainfall and the backward agricultural communities are hardly members of societies." 55 Data on loan sizes and collateral requirements on those loans signals the income profile of borrowers. Loans exceeding 250 rupees (Rs) accounted for nearly half of all cooperative credit provided in 1930 and $1956.5^{6}$ Loans from moneylenders were significantly smaller, suggesting that moneylenders rather than cooperatives were servicing the credit needs of the poor. Indeed, from a survey of moneylender-serviced credit markets in six villages in the Bellary district, the average debt per acre was Rs 17 in $1930 .{ }^{57}$ Assuming the size of loans increased proportionally to the size of land ownership, these numbers suggest that cooperatives showed a preference for highincome borrowers.

Furthermore, cooperatives shifted from non-asset-based to mortgage lending from the 1920s. In the mid-1920s, mortgages accounted for 40 percent of loans, while borrowers accessed the majority of cooperative credit by attaching a cosigner to their loan applications. By 1938 , 60 percent of loans were secured by mortgage instruments. The government recognized that this was a departure from the original aims of the cooperative movement. Commenting on foreclosures in 1936, the Cooperative Department in Madras stated that "these properties are undoubtedly a source of embarrassment to societies and it must be their anxious concern to dispose of them in consultation with their financing banks at the earliest opportunity." ${ }^{8}$ Cooperatives that

\footnotetext{
$5^{2}$ Report of the Committee 1956, 41.

${ }^{53}$ Naidu, "Co-operative Movement," 420.

${ }^{54}$ Report of the Committee 1956, 40.

${ }^{55}$ Rural Credit Survey, 223.

${ }^{56}$ Provincial Banking Enquiry Report, 152; Report of the Committee 1956, 29.

${ }^{57}$ Provincial Banking Enquiry Report, 62-63.

${ }^{5}$ Annual Report 1936, 12.
} 


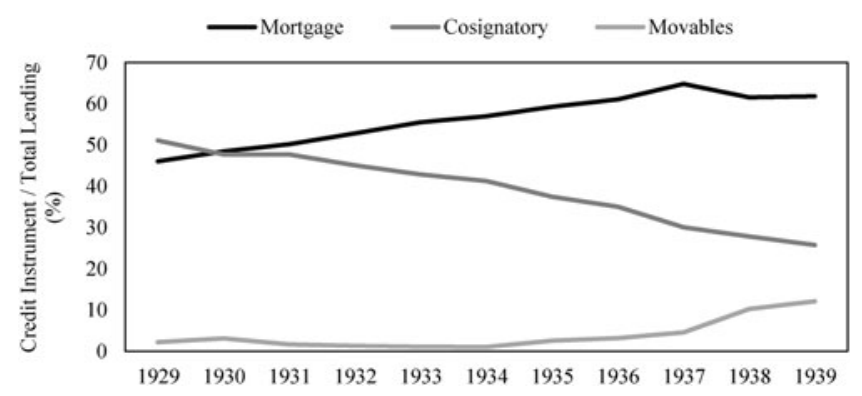

Figure 1. Security on loans, 1928-1939. Figure shows the value of loans attached to three credit instruments. "Mortgage" refers to loans secured by land. "Cosignatory" refers to loans contractually secured by third-party guarantors. "Movables" refers to loans secured by crop. The source provides the total volume of lending by primary banks in a given year, disaggregated to the volume of loans under the three types of credit instrument in a given year. Ratios calculated and converted to percentages in the source. (Source: Annual Reports on the Working of the Co-operative Credit Societies Act [Madras, 1928-1939].)

acquired land from their members contradicted Nicholson's principles of Raiffeisen banking (see Figure 1). Collateral requirements excluded poor peasants from accessing cooperative credit.

The Great Depression explains the shift from cosignatory lending to mortgages. 59 The cosignatory method proved unsustainable during the 1930 s crisis. Repayment rates were generally low in cooperatives. From loans issued in the late 1920s, primary banks declared 30 percent of expected interest inflows as overdue. As Figure 2 illustrates, recovery rates continued to decline as overdue interest increased by a further 30 percent between 1930 and 1934. Primary banks shifted to mortgage lending in the hope that auctioning the land acquired from defaulters would help mitigate losses. The colonial government enforced rules that ensured each cooperative limited the total value of loans to the net value of properties held in its possession. ${ }^{60}$ Cooperatives enforced this parameter to moderate the difference between the value of the properties securitized and the value of overdue loans. The rules entitled cooperatives to liquidate properties in times of default. The provincial government expected cooperatives to generate positive net balances by auctioning land they acquired from defaulters.

Recovery from the Depression started from 1937. Membership in primary banks increased by 2.6 percent between 1937 and 1938, with a

\footnotetext{
${ }^{59}$ Homogeneity in the occupation of borrower members spread the impact of the crisis. Cultivators constituted 89.1 percent of the total membership of primary banks (Annual Report 1929, 9). The commodity price crash in the early 1930 s led to a rapid short-term decline in the membership of primary banks (Annual Reports 1929-1934).

${ }^{60}$ Provincial Banking Enquiry Report, 151.
} 


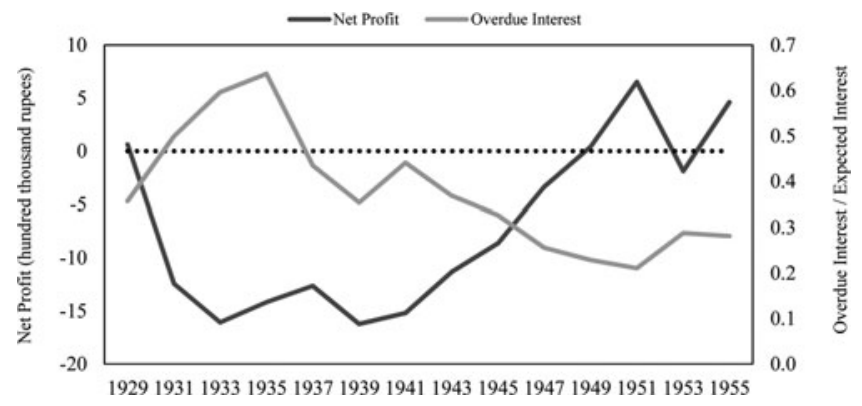

Figure 2. Profitability of primary banks, 1929-1955. Figure shows that primary banks incurred losses throughout the period. The government collected data from each primary bank and aggregated this to the provincial level in the source. Profit and loss calculations by the author. "Net Profit" shows the difference between divisible profit and non-recouped loss in a given year. The dotted line indicates when primary banks break even. "Overdue Interest" is calculated in the source; it measures default rates in a given year by estimating the ratio of unpaid interest to total interest obligations. For example, in 1934 the ratio of overdue interest to interest due was 0.64 , which means that primary banks recovered only 36 percent of their expected interest inflows that year. (Source: Annual Reports on the Working of the Co-operative Credit Societies Act [Madras, 1928-1939]; Report of the Committee on Co-operation in Madras [Madras, 1956], 425-35.)

larger increase of 8.3 percent over the following year. Primary banks expanded lending operations in the same period. The value of loans provided by primary banks in 1939 was 1 percent shy of the same measure in 1929. This was supported by rising commodity prices in the early $1940 s .{ }^{61}$ However, cooperatives did not fully recover from the crisis. As Figure 2 demonstrates, primary banks reported net losses until 1950. The upward swing in commodity prices and the shift to mortgage lending had a limited impact on the profitability of cooperative banks. Why did cooperatives endure losses despite the move to more selective lending?

One potential answer is that cooperatives were constrained by enforcement costs. Institutional barriers prevented banks from acquiring land in a timely and cost-efficient manner. Land transfer required the ratification of legal authority and court disputes were lengthy and expensive. ${ }^{62}$ The colonial government created a legal structure, for cooperative banks, that functioned outside the scope of civil courts. The 1932 Madras Co-operative Societies Act specified that cooperative disputes were to be resolved by representatives of the Registrar, as

\footnotetext{
${ }^{61}$ Michelle McAlpin, "Price Movements and Fluctuations in Economic Activity (186o1947)," in Kumar and Desai, Cambridge Economic History, 878-904, appendix table 11A.1.

${ }^{62}$ Roy and Swamy, Law and the Economy.
} 
chair, of the cooperative department in the provincial government. ${ }^{63}$ The government created special arbitration courts within districts to enforce land transfers following defaults. ${ }^{64}$ These forums failed to solve the problem. The rising number of pending disputes in the early 1930 s triggered concerns among policymakers that arbitration courts were also a costly and inefficient method of enforcing repayments. ${ }^{65}$

However, enforcement barriers do not fully explain losses in the cooperative sector. According to Nicholson's prototype, self-help should have substituted external enforcement in the first instance. The requirement for courts in itself represents a failure in cooperation among members. The next section shows that cooperatives shifted to mortgage lending and incurred persistent losses because of flaws in capital structure and regulatory design.

\section{Low Savings and Weak Regulation}

Primary banks were not self-funded and borrowed from district banks to fund their lending operations in Madras. High savings in district banks and low savings in primary banks entrenched a banking structure of debt dependence. As a result, primary banks were poorly regulated. Low savings restricted the capacity for mutual supervision in primary banks. Top-down regulation did not substitute for the absence of this bottom-up supervision. As mentioned before, the entire banking system in India did not have a formal regulator until the 1949 Banking Regulation Act, and even that act did not cover cooperatives. ${ }^{66}$ The outcome of the flawed design was weak regulation and mismanagement.

As Figure 4 illustrates, primary banks in Madras raised most of their working capital through external borrowing. ${ }^{67}$ Loans from district banks financed between 70 percent and 80 percent of the required working capital in primary banks. Members' and nonmembers' deposits

${ }^{63}$ Section 51 of the Madras Cooperative Societies Act (VI of 1932).

${ }^{64}$ Arbitration forums were the preferred forums of appeal for banks and defaulters alike. The number of cooperative disputes in arbitration forums exceeded appeals in civil courts by a significant margin.

${ }^{65}$ Annual Report 1937, 10.

${ }^{66}$ The Indian government modified the 1949 Banking Regulation Act to include cooperatives in 1965. On laws and private banking in the colonial period, see Roy and Swamy, Law and the Economy. For a discussion of the Banking Regulation Act, see Autar K. Koul and Mihir Chatterjee, "International Financial Institutions and Indian Banking: A Legal Profile," in India and International Law, ed. Bimal N. Patel (Leiden, 2008).

${ }^{67}$ The ratio of external borrowings to working capital declined from 74 percent to 60 percent between 1928 and 1935, coinciding with a rise in the ratio of reserves to working capital from 6 percent to 16 percent in the same period. Banks were either liquidated or more risk-averse during the Depression. The temporary decline in the ratio of external borrowings in the 1930 does not infer greater self-sufficiency. 


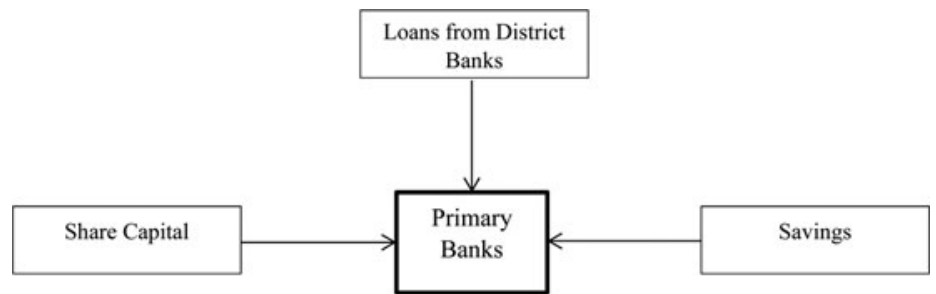

Figure 3. Sources of working capital for primary banks, 1930-1960. (Source: Annual Report on the Working of the Co-operative Credit Societies Act 1929 [Madras, 1928-1939]; Report of the Committee on Co-operation in Madras [Madras, 1956].)

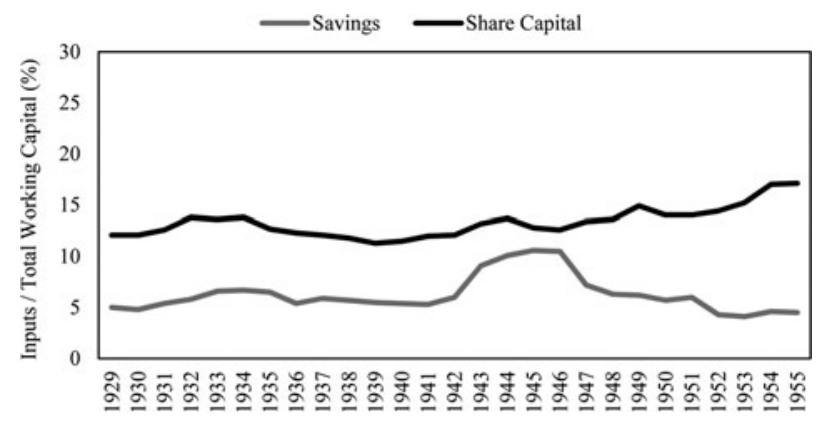

Figure 4. Ratio of savings and share capital to working capital, 1928-1955. Figure shows savings and share capital constituted a small share of the working capital in primary banks. The sources provide data on the total working capital of primary banks with the value of savings, investment and debt. For ease of comparison, the author rounds all numbers to the nearest 10,000. The reports exclude data from the Ganjam district in 1936-1937. Data scope shifts from "composite" to "residuary" state in 1953 to reflect the changing of state borders after independence. These two factors do not bias the results in any way. (Source: Annual Reports on the Working of the Co-operative Credit Societies Act [Madras, 19281939]; Report of the Committee on Co-operation in Madras [Madras, 1956].)

accounted for between 5 percent and 11 percent of total working capital. Share capital played a marginally more important role than savings in primary banks; however, share capital included investments from members and district banks. The majority of this investment was from district banks in the 1930s, accentuating the external funding problem. ${ }^{68}$ Why were savings low in primary banks? Colonial officials maintained that peasants were ill informed about the benefits of saving such that disposable income was rarely saved and instead spent on extravagant ceremonies. ${ }^{69}$ In practice, rural cultivators faced two

${ }^{68}$ Annual Report 1936, 30-31.

${ }^{69}$ See Malcolm Darling, The Punjab Peasant in Prosperity and Debt (Bombay, 1947). 
barriers to saving. First, savings rates were low because harvest failure was common and cultivation was unprofitable in bad years. An indirect confirmation of the claim that volatile seasonal incomes depressed rural savings is that the ratio of saving to working capital was higher in urban cooperatives during the same period. ${ }^{\circ 0}$ Second, rich peasants did not save in primary banks. Two factors explain this outcome. First, cultivators invested disposable income in the credit market as moneylenders. ${ }^{71}$ According to P. G. K. Panikar, "90 per cent of rural credit [in the 1950s] seems to come from the saving of rural families." 72 Moneylending presented a more lucrative option to saving. As mentioned, a gap existed between the interest rates charged on loans from moneylenders and those offered by cooperative banks. Second, rich peasants saved in district banks rather than primary banks. A marked increase in the number of individual depositors in district banks occurred in the late 1920s. ${ }^{73}$ The ratio of savings to loans in district banks was significantly higher than the same ratio in primary banks. At the peak of the Depression, in 1933-1934, savings deposits accounted for 62 percent of the total working capital of district banks. A combination of share capital and savings contributed 72 percent of total working capital in the same year. 74

Rich peasants chose to save in district banks because, based on the government's design, the deposits of members and nonmembers in district banks had a stronger guarantee than deposits in primary banks. Individual depositors were not the only savers in district banks. Local government departments saved, as did groups of primary banks. The colonial government framed laws to ensure that primary banks maintained a reserve ratio, physically deposited in district banks. According to the laws, primary banks deposited this "statutory contribution" in the district bank to which they were indebted.75 This required reserve increased the value of deposits in district banks. When primary banks defaulted on loans to district banks, the reserve fund diminished before savings. Moreover, groups of primary banks borrowed from and deposited reserves in one district bank. District banks offset the defaults from one primary bank with the reserves of another. ${ }^{76}$ District banks also restricted the volume of lending to failing primary banks. Indeed, district banks maintained higher reserves and reduced lending to primary banks

\footnotetext{
${ }^{70}$ Annual Reports 1928-1939.

${ }^{71}$ Report on Agricultural Indebtedness, 43.

${ }^{72}$ P. G. K. Panikar, Rural Savings in India (Bombay, 1970), 59.

${ }^{73}$ Annual Report 1936, 19.

${ }^{74}$ Annual Report 1934, 24.

${ }^{75}$ Annual Report 1930, 16-17.

${ }^{76}$ Annual Report 1936, 19.
} 
in the 1930 . ${ }^{77}$ Deposits from primary banks and risk-averse lending in crisis years, both enforced by government regulation, protected member and nonmember deposits in district banks.

The Depression had a larger impact on primary banks than on district banks. Between 1929 and 1939, district banks reported a decline in net profits from Rs 1.1 million to just over Rs 300,000. In the same decade, primary banks transitioned from earning a net profit of Rs 60,000 to reporting net losses of Rs 1.62 million. ${ }^{78}$ Reserves and higher savings in district banks moderated the transmission of primary bank losses up the cooperative ladder. The combination of share capital, savings, and reserve deposits constituted 77 percent of the total working capital of district banks in 1933-1934.79 Deposits insured defaults, restricting the losses incurred. In contrast, primary banks were funded by external borrowing. Defaults were high and deposits were small, leading to persistent losses.

Low savings posed a problem for supervision in primary banks. Members of cooperative panchayats, including presidents and secretaries, were commonly neither savers nor shareholders. The incentive for self-contained supervision diminished as the burden of default was not borne by the deposits or share capital of governing members. According to Eleanor Hough's thesis on the management of Indian cooperatives in the early 1930s, "the cooperative safeguards of mutual watchfulness and supervision are absent and everything depends on the committee's honesty and business ability." 80 This problem persisted throughout the period. On the management of primary banks, the Rural Credit Survey in 1954 reported that "there is a paucity of members who are actually cultivating lands themselves. The agricultural finance by the co-operatives would be more efficient and smooth if ways and means are devised to secure invariably the presence of some actual cultivators on the board of management." ${ }^{1}$ The employment of professional managers rather than shareholders resulted in a lack of monetary incentives to increase the profitability of primary banks. The provincial government reported the following in 1929:

Though the objects of co-operative banks and commercial banks may be different, the one seeking to increase the shareholders' profit being

\footnotetext{
${ }^{77}$ The volume of district bank to primary bank loans halved between 1929 and 1935 (Annual Reports 1929-1935).

${ }^{78}$ Annual Reports 1928-1939.

${ }^{79}$ Annual Report 1934, 50-51.

${ }^{80}$ Eleanor M. Hough, The Co-operative Movement in India: Its Relation to a Sound National Economy (London, 1932), 60. While affiliated to George Washington University in the early 1930s, Hough wrote a doctoral thesis on the cooperative movement in India.

${ }^{81}$ Rural Credit Survey, 263.
} 
ruled by shareholders who have generally no other interest in the concern, while the other seeks to benefit the borrower shareholder, whose interest as borrower is far greater than his interest as shareholder. ${ }^{82}$

In other words, the governance structure in primary banks did not foster sound management through self-regulation. ${ }^{83}$

Supervising unions did not solve the problem either. By 1931, there were 431 supervising unions in rural Madras alone. ${ }^{84}$ However, the government did not design unions to hire external supervisors. Officials were concerned that external supervision would lead the cooperative movement to depart from its aims of being self-contained within villages. In his capacity as Joint Registrar of Cooperative Societies in the Madras government, K. Deivasikhamani Mudaliar stated in 1937 that "for the efficient administration of village societies local knowledge and help is essential. The money lent to the villagers can be recovered easily only with their help. Nothing can be done in a village without the help of the villagers." 85 Accordingly, the government implemented policies to ensure that supervision remained within the scope of the managers of primary banks. Members of supervising unions constituted representatives from the panchayats of primary banks. As a result, the governance structure of supervising unions extended, rather than corrected, the lack of management accountability in primary banks. Supervising unions, as recorded in an official report in 1935, "cannot be independent and disinterested bodies, as they are run mostly by representatives of the very societies, which have to be supervised. Is it any wonder then that the supervisor is often forced, if he is to keep his job, to collude with the managements of credit societies in all their misdemeanours?"86

The reference to misdemeanor is significant. The government supplemented supervision with annual audits of primary banks. Audits were initially voluntary and paid for by the banks themselves. ${ }^{87}$ This changed with the rising number of defaults in the late 1920s. From the early 1930s, annual government audits were compulsory for all

\footnotetext{
${ }^{82}$ Annual Report 1929, 17.

${ }^{83}$ One potential barrier to self-regulation was illiteracy. Members needed a basic understanding of loan accounting and contracts to effectively supervise banks. However, certain institutional arrangements solved the problem in Madras. The Provincial Banking Enquiry reported in 1930 that cultivators approached local schoolteachers and clerks competent in simple accounting methods to assist in analyzing loan documentation. Moreover, the provincial government established cooperative training institutes in districts. The institutes provided free assistance to illiterate members.

${ }^{84}$ Naidu, "Co-operative Movement," 427.

${ }^{85}$ Madras Journal of Co-operation 1936, 510.

${ }^{86}$ Report on Agricultural Indebtedness, 60.

${ }^{87}$ Section 17 of the 1912 Co-operative Societies Act allowed for panchayats to audit primary banks.
} 
primary banks. Regular audits exposed the frequency of fraudulent lending practiced by the managers of primary banks. The frequency of management fraud became more apparent during the Depression. According to one official report in 1931, "in the prevailing tightness of the money market defaulting secretaries were no longer able to restore the stolen funds on the approach of an inspection."88

Auditors provided certificates to all banks at the end of every audit. Certificates contained a grade, ranging from A to D. Government auditors branded Class A banks "thoroughly good societies" while Class D banks were "bad societies which probably have to be liquidated." In the financial year 1932-1933, the government audited 13,425 banks, of which 1,735 banks were in the D group. ${ }^{89}$ Auditors carried out additional scrutiny of banks with the largest defaults, to identify areas of mismanagement or, in severe cases, fraud. In the same year, seventy-seven cases of fraud were pending criminal prosecution. Arbitration forums charged eighty-seven individuals in total, of whom seventy-seven held management positions in primary banks. $9^{\circ}$ Numbers of criminal prosecutions for the misappropriation of funds were consistent throughout the 1930s. As recorded in 1936, "There are no signs of diminution in cases of defalcation; the department does its best to purge the movement of dishonest members but obviously can do little unless honest men come forward to run the societies." 91

On discovery of misconduct, employees from district banks or the provincial government superseded the management board of the mismanaged primary bank. In 1935, audit reports from the Krishna district exposed mismanagement in a regional cluster of primary banks. Employees from its financing district bank, the Krishna District Co-operative Bank, subsequently took control of the management of these banks. ${ }^{92}$ Following the supersession, the provincial government liquidated banks that failed to achieve a grade above D.

Managers practiced two types of misconduct, one more serious than the other. The first, and less serious of the two, was insider lending. Evidence shows that managers provided loans to members of the same caste. The social composition of management boards in the cooperative sector in the North Arcot district in the early 1920 s provides evidence of this form of discriminatory lending. There were 30,000 members of primary banks in the district, 2,700 (or 9 percent) of whom were Brahman. According to one report, six out of seven directors of the

\footnotetext{
${ }^{88}$ Annual Report 1931, 17.

${ }^{89}$ Annual Report 1933, 8.

${ }^{\circ}$ Annual Report 1933, 14

${ }^{91}$ Annual Report 1936, 17.

${ }^{92}$ Madras Journal of Co-operation 1935, 324.
} 
district bank and twelve out of fourteen supervisors of primary banks were from the Brahman caste. The managers of primary banks in the district allocated the majority of loans to Brahman members, while default rates saw a steady increase in the 1920 s. By the early 1930 , the government had liquidated eleven of thirty supervising unions in the district for "inefficient supervision and mismanagement of affairs."93

The second type of management malpractice was embezzlement. Bank managers siphoned money for personal benefit. Legal records from the 1930 s provide evidence of managers who issued loans either to themselves or to a network of their relatives. In the 1933 dispute Re: Patri Venkata Hanumantha vs Unknown, for example, the secretary of a cooperative in the Guntur district was found to have issued large sums to either himself, his brother, or his cousin at regular intervals in the late 1920 s and early 1930 . Managers forged contracts, declaring fake names and mortgage securities. Borrowers did not repay loans and managers declared those loans as unrecovered principal in the bank's account books. The prosecution argued that "while the depletion in the resources of the bank was taking place on account of the series of misappropriations slyly committed by the 1st accused, the financial equilibrium of the bank became patently unstable and on account of the large overdues there was pressure from several quarters."94 Recipients of loans, including the secretary of the bank, were indicted with prison sentences of ten years while those convicted of abetting the crime were sentenced to seven-year imprisonments.

Bank managers embezzled to lend at high interest rates in the informal credit market. Members of the managing committee were either "trader, moneylender or shopkeeper" in seven out of nineteen surveyed primary banks in the Coimbatore district in 1957. Similarly, members of the management board were moneylenders in eight out of nineteen surveyed banks in the West Godavari district. The Rural Credit Survey reported that the vested interests of administrators-cum-moneylenders "worked against the interests of the society" they were managing. 95 From the recorded banks in Table 3, the report on bank W3 in the West Godavari district stated that the "President was very powerful and used to take benami loans-traders and landlords were on the managing

\footnotetext{
${ }^{93}$ Madras Journal of Co-operation 1936, 88.

${ }^{94}$ Re: Patri Venkata Hanumantha vs Unknown (1934 66 MLJ 193, Madras, 6 Oct. 1933). Case records report similar methods of misappropriation throughout the period. In the case Most Revd. Dr. L. Mathias, S.C., the Archbishop of Madras and the President of the Catholic Indian Association and Another Vs. Kilacheri Agricultural Co-operative Bank (1938 1 MLJ 241, Madras, 5 Oct. 1937), the secretary of the Kilacheri Agricultural Co-operative Bank accepted deposits on behalf of the bank. The secretary subsequently embezzled these funds.

${ }^{95}$ Rural Credit Follow-Up Survey, 446.
} 
committee."96 The bank reported a 100 percent ratio of overdue repayment to outstanding loans. The government disbarred the bank from lending in 1954. Similarly, the Rural Credit Survey reported the following of a primary bank in the Coimbatore district:

Society $\mathrm{C}_{5}$, organised in 1919, was dominated by landowners. The expresident misappropriated funds by making unreceipted collections. Since then, the members lost confidence in the society which gradually stopped functioning. Improper management, lack of proper supervision and timely help from the central bank and Co-operation Department resulted in misappropriation and consequent deterioration in the financial position of the society. 97

Audits failed to restrict embezzlement for two reasons. First, siphoned money was left undetected as managers falsified accounts. Audits of primary banks commonly yielded inaccurate reports..$^{8}$ As one official report in 1956 suggested, "as a result of its inability to employ paid staff, account-keeping leaves much to be desired and naturally demands more of the time of the supervisory and audit staff." 99 This feature of primary banks persisted throughout the period. Approximately 92 percent of audited banks in 1934 were reported to have defects in their account books. ${ }^{100}$ Similarly, as Table 3 shows, ten of nineteen surveyed primary banks in the Coimbatore district in 1957 were reported to have errors in accounting. Managers recorded defaults as extensions rather than overdue repayments in the balance sheet of primary banks. This lack of accounting transparency was a barrier to efficient regulation.

Second, the provincial government did not supplement audits with effective enforcement. Scholarship on cooperatives in Germany demonstrates that the publication of management dishonesty to various stakeholders ensured that managers did not resort to fraud. ${ }^{101}$ Some government officials in 1930 s Madras also recognized the importance of this form of social enforcement. One report in 1935 suggested that "the maximum of publicity is required. This was Raiffeisen's [in the German context] great maxim." The report proceeded to comment that "audit reports are not even opened and read for years together, meetings

\footnotetext{
${ }^{96}$ Rural Credit Follow-Up Survey, 731. Benami literally translates as "without name." In this context, it refers to the practice of managers lending to accounts attached to fictitious holders. The accounts belonged to either the managers themselves or their relatives.

${ }^{97}$ Rural Credit Follow-Up Survey, 363.

${ }^{98}$ Strickland, "Coöperation," 515-17.

${ }^{99}$ Provincial Banking Enquiry Report, 151.

${ }^{100}$ Annual Report 1934, 16. Auditors reported that 12,550 out of 13,552 banks had defects in their account books.

${ }^{101}$ Guinnane, "Friend and Advisor."
} 


\section{Table 3}

Survey of Primary Banks in Two Districts, 1956-1957

\begin{tabular}{lcccc}
\hline District & Banks & Legible accounts & Erroneous accounts & Failed audit \\
Coimbatore & 19 & 9 & 10 & 8 \\
West Godavari & 19 & 17 & 2 & 3 \\
\hline
\end{tabular}

Source: Rural Credit Follow-up Survey (Bombay, 1960), 687-96.

Notes: "Legible accounts" in this survey measures the number of banks with error-free account books. "Erroneous accounts" measures the number of banks that had errors in their account books. "Failed audit" measures the number of banks with audit certificates of $\mathrm{C}$ grade and below. Savings were either negligible or nonexistent in all banks. The survey anonymized the names and management board members of all banks.

are not held to consider such reports and members are not kept informed of their financial position." ${ }^{102}$ Managers were apparently unafraid of failed audits. According to one report, "if panchayats who know their duties and responsibilities deliberately abuse their position, it cannot be effectively prevented. You may close the society for this reason but the mischief is already done. Therefore, supervision alone may not bring about the reform necessary in societies."103

So, primary banks reported persistent losses due to low savings and weak regulation. However, the expansion of the cooperative sector in the 1940 s and 1950 os presents a paradox. A new level of state intervention explains this puzzle.

\section{State Intervention: Prolonging Banking Failure}

The provincial government did not lend to cooperatives and restricted its participation to conducting annual audits in the colonial period. District and municipal government departments saved unspent revenue in district banks. However, the value of government deposits was lower than the savings of members and nonmembers in the district banks. ${ }^{104}$ The postcolonial government adopted a more interventionist stance in the late 1940s. While state officials did identify a problem in the failure of cooperative banks to be both equitable and profitable, the newly formed government believed capital injections into the cooperative sector was the solution.

The risk of participation in a fragile banking sector motivated the colonial government's passive stance. Loans from government

\footnotetext{
${ }^{102}$ Report on Agricultural Indebtedness, 63.

${ }^{103}$ Madras Journal of Co-operation 1936, 511.

${ }^{104}$ Report of the Committee 1928, 18-22.
} 


\section{Maanik Nath / 82}

accounted for a negligible share of the working capital of primary banks in the 1930s. The ratio of government loans to the total working capital of primary banks fluctuated between 0.7 and 1.7 percent between 1928 and 1939. ${ }^{105}$ Government loans were not provided either to district banks or to the provincial bank in the same period. The Indian central bank, Reserve Bank of India (RBI), in particular, played a limited role in the cooperative movement during the colonial period. Deposits from commercial banks formed the majority of the reserves held by the RBI. Rather than lend the savings of large commercial banks to risky rural cooperatives, the RBI adopted a noninterventionist approach to the cooperative movement. Justifying this noninterventionist stance in the Bombay Co-operative Quarterly in 1938, the RBI stated,

The sum and substance of the lengthy memorandum is that while the Reserve Bank is willing to offer advice and even to direct and control co-operative finance it is not willing at present, for various reasons, to deal with provincial co-operative banks-in the case of some because they are not creditworthy, in the case of others because they have established their credit and possess resources themselves. ${ }^{106}$

The end of colonial rule marked a turning point in the role of the RBI in the cooperative movement. The government's First (1951) and Second (1956) Five-Year Plans focused on increasing intervention in rural credit through greater participation in cooperatives. The government attributed the limited success of cooperatives in displacing informal sources of credit before 1947 to liquidity constraints in primary banks. Accordingly, the First Five-Year Plan proposed large capital injections into the cooperative machinery to drive out moneylenders from rural credit markets. This increase in state participation did not translate to a direct interaction with primary banks.

The RBI extended large volumes of credit to district banks from the late 1940s. The first disbursement of loans to district banks took place in 1947. Between 1947 and 1951, the value of state financing to district banks increased by over five times. ${ }^{107}$ The capital injection into district banks did translate into an increase in the loans provided by primary banks. Indeed, there was a significant rise in membership and working capital in primary banks from the late $1940{ }^{108}$

Government officials perceived the growth in membership and lending as a success. It was a sign that cooperatives were able to

\footnotetext{
${ }^{105}$ Annual Reports 1928-1939.

${ }^{106}$ S. L. N. Simha, History of the Reserve Bank of India (Bombay, 1970), 207.

${ }^{107}$ Simha, 782.

${ }^{108}$ Report of the Committee 1956, 425-28.
} 
capture a greater share of the credit market from village moneylenders. Accordingly, government reports in the early 1950 os sustained the position that undercapitalization was a primary driver of cooperatives' failure in the pre-1947 period. ${ }^{109}$ The desire for increased capitalization led to a further enhancement in state financing to district banks in the late 1950s. The government established various initiatives, involving the allocation of public funds to rural cooperatives to achieve two aims. First, as mentioned, to enhance the capitalization of rural cooperatives in general. ${ }^{110}$ State governments significantly increased their subscription of share capital in district banks during this period. Second, the government allotted public funds to some cooperatives in crisis years, particularly the banks incurring losses because borrowers were impacted by environmental shocks and crop failure. ${ }^{111}$

However, the level of savings in primary banks did not increase at the same rate as the level of state financing. The rate of growth in central bank loans exceeded the growth rate in savings during the late 1940s. Between 1947 and 1952, the ratio of savings to working capital in primary banks declined from 7 percent to 4 percent (see Figure 4). In other words, the transition in 1947 did not change the legacy of low savings. The ratio between savings and external borrowings widened as primary banks were less self-funded than they had been before receiving financial assistance from the RBI. According to data from the $1940 \mathrm{O}$ and 1950s, loans from district banks continued to finance the loans provided by primary banks. Data on the primary banks shows that the ratio of external borrowings accrued to loans issued varied between 90 percent and 130 percent between 1947 and $1955 .{ }^{112}$

In short, problems in the cooperative sector in the colonial period were carried forward into the postcolonial period. Governments intervened in cooperatives through financial contributions with limited impact on capital structure and regulation. Low savings perpetuated the lack of bottom-up supervision. Managers of primary banks continued to be held accountable by ineffective top-down regulation. To make matters worse, public revenue was being allocated to a failing banking sector in the postcolonial period. This added moral hazard to the list of problems in cooperative banking in postcolonial South India.

\footnotetext{
${ }^{109}$ Report of the Committee 1956, 8-10.

${ }^{110}$ The National Agricultural Credit Fund, managed by the RBI, provided loans to state governments. The governments used the loans to invest in district bank shares.

${ }^{111}$ The National and State Cooperative Development Funds, also managed by the RBI, extended credit to cooperatives that reported high default rates because of harvest failures.

${ }^{112}$ Report of the Committee 1956, 425-30.
} 


\section{Maanik Nath / 84}

\section{Conclusion}

Policymakers in colonial India identified market failure in rural credit as the driver of persistent rural impoverishment. They believed that cooperative banking would solve the problem by both expanding the supply of credit and restricting the monopoly power of the moneylender. Tested success of Raiffeisen banks in Europe inspired the government to create a structure of self-help banking in India from the early twentieth century. However, this intervention failed to deliver the desired outcome. Cooperative banks rationed credit for many poor borrowers; despite expansion in size, cooperatives captured a small share of the business, and they were unprofitable throughout. This article investigates the reasons behind the persistence of these problems by showing where the Indian model departed from the stylized Raiffeisen one in the province where the experiment began.

One part of the explanation consists of showing how low savings reduced the role for self-supervision. The government created a threetier banking structure that included primary banks, district banks, and a provincial cooperative bank. In the primary banks, depositor and shareholder members were few and borrower members were many. Richer peasants crowded the top end of the cooperative hierarchy as depositors, while poorer peasants crowded the bottom end as borrowers. Deposits in district banks had a stronger government guarantee than deposits in primary banks. This design flaw allowed the rich to refuse to cooperate with the poor. There was limited mutual supervision as managers were not held accountable by members.

External regulation could potentially solve the problem. The government established supervising unions and a top-down regulatory structure including annual audits and a defined process for the liquidation of insolvent banks. However, embezzlement and insider lending persisted as the interests of the supervisors, auditors, and managers conflicted. Although available sources omit the details of the problem, they suggest that regulatory flaws lay in its design. The laws governing regulation were designed not by the banking regulator but by the provincial government. Enforcement was compromised, especially where bank managers carried social and political influence.

Though dysfunctional, the cooperative structure survived. The state allocated public revenue to cooperative banks. Local government departments deposited unspent revenue in district banks during the 1920 s and 1930s. The state expanded its financial participation in the cooperative sector in the 1940s. Large capital injections were made into primary banks from 1946. State intervention altered the capital structure of the cooperative sector. Whereas primary banks were debt dependent to 
apex banks in the 1930s and 1940s, the 1950s introduced the government as the source of lending in the rural credit market. Financial contributions from the state entrenched the problem of moral hazard into cooperative banking in postcolonial India. The problems of dependence on external funds, regulatory failure, and losses, therefore, persisted.

The study offers larger lessons on the challenges of top-down cooperative banking promotion in poor agrarian societies. One lesson is that economic inequality and unequal sociopolitical influence among rich and poor peasants prevented cooperation in Indian villages. The article goes further. It analyzes institutional and policy regimes and suggests that a small section of the rural population benefited from loss-making cooperative banks as a result of a lack of management accountability. Cooperative transplants required a regulatory structure that supported efficient banking. Additional capital injections into a fragile transplant extended rather than solved structural failures. For the governments in colonial and postcolonial India, providing easy access to credit was the central objective. The cooperative organization was a casualty of this policy.

Further research could expand on the impact of banking regulation by the executive, rather than independent regulators, on the performance of cooperatives. In group lending arrangements, the expectation is that local and insider supervision would ensure efficient management. This case study of Madras suggests that internal supervision was not a sufficient condition, especially when savings rates were low. External regulation was needed. Cooperative banks in India continued to report losses after 1960, suggesting that the lessons drawn from early twentieth-century Madras are indeed robust.

MAANIK NATH is a Postdoctoral Fellow in Economic History at the London School of Economics and Political Science. This article builds on one part of his doctoral thesis. The thesis is titled, 'The State and Rural Credit Markets in South India, 1930-1960.' 